\title{
Aged Society: The Way Forward
}

\author{
Siti Norfazlina Yusoff and Geogiana Anak Buja
}

\begin{abstract}
Many countries have experiencing aging population, due to better healthcare services and higher education among citizen. In Malaysia, the country also facing the same emerging trend, in which the demographic profile of Malaysian experiencing the major shift. The life expectancy of Malaysian has increased in year 2012 with the average of $\mathbf{7 3 . 8}$ years or equal to 71.1 years for males and 76.7 years for females. This phenomenon has spawned into the public sector and forced the government to take a prompt action by increasing the retirement age of public servant from 58 to 60 years old. However, it has created new challenges towards young entrance, especially in the public sector. SEDAR and CUEPACS have different views on this issue, in which it has been debated from the country's standpoint. The Malaysian National Policy for Elderly hasits own loophole within;make the policy become less comprehensive in the views of aged. Therefore this paper aims to provide an overview of Malaysia's situation of elderly and its impact towards the country's growth.
\end{abstract}

Index Terms-Aging population, public sector, financial security, national policy.

\section{EMERGING TREND}

Ageing population remains a global phenomenon in this 21 st century and has changed the demographic profile of many countries, experiencing the major shifts, especially in supplementing a pool talent of workforces [1] Therefore the human capital is really important for every country as an engine of growth in measuring performance, development and achievement purposes. Less supply of workforces within the country against higher demand from employers make the condition become worse. It will distort the development process, perceptibly affected the objective of the country for the long term basis, as Malaysia aiming to be a developed country by year 2020 . Consequently, this has alarmed those countries that experiencing an increasing of ageing population to take an effective solution without marginalized aged society. There are 61 countries that currently have below replacement level birth-rate, based on United Nations [2]. Several couples of years, there were no countries experiencing ageing quickly as Japan does, though many other industrialized countries now are following Japan's demographic footsteps. Japan is one of the most rapidly ageing countries in the world with the life expectancy for male is 79 years old and female is 85.7 years old. In fact in Australia, the population ageing has become the main debate whereby it has placed a great pressure on Australia Workforce management [3]

Manuscript received April 25, 2013; revised July 20, 2013

Siti Norfazlina Yusoff and Geogiana Anak Buja are with UniversitiTeknologi Mara (UiTM), Malaysia (e-mail: fazlina836@kedah.uitm.edu.my).

\section{Malaysia AND Ageing Population}

Malaysia is not leaving behind in terms of aging population whereby, the country also gradually experiencing on this. As one of the developing countries in South East Asia with the approximately 29 million (2012) of the population, Malaysia will become the victim of this occurrence. According to [4] the proportion of elderly in Malaysia has been projected to increase from 6.3 per cent in year 2000 to 12.0 per cent or 4.9 million persons by the year 2030. The median age for Malaysia population has increased from 23.6 years to 26.8 years for year 2000 and 2012 respectively. In fact the dependency ratio has contributed the amount of burden of support in which placed on the existing workers which is 15 to 59 years. Noticeably, this will increase the burden of support on the working age population with the ratio declining from 82.6 in 1980 to 64.3 in 2000. Life expectancy in Malaysia has also increased in year 2012 with the average of 73.8 years or equal to 71.1 years for males and 76.7 years for females [5]. Not only that, the family structure in Malaysia is fast changing due to modernization and urbanization process. The modernization and urbanization process have forced the young adult live separately with their parents. Therefore it will place more pressure on the children's ability in taking care of family especially their aged parents. Additionally it becomes worse since the composition of extended family seems to be declined and nuclear family begins to take place. Consequently the children have no more or less ability and responsibility to take care for elderly parents, and some of them were getting married and have journeyed to other dwellings. In developed countries such as Japan, the family size is declined due to modernization process. Better position, high self-actualization and long working hour may lead to inability in concentrating on family matters. As a consequence, they have no time to take a look of their family including their parents. Indeed, the other factors that worsening this issue is the elderly seems to be sharply increased by 2030, nearly 24 per cent and the age are expected to be at least 85 years old [6]. This unsolicited situation may result a punitive and compression either financially or vitality on the young population [refers to children] [7]. Substantial effect has awaked policy makers in Malaysia to regulate more comprehend policy concerning elderly. According to [8] argued that majority of the Malaysian elderly have depended on adult children in maintaining their life instead of formal sources such as pension. Therefore, the children can be one of the financial sources after getting retired. According to the research that has been done by [9] 50\% of older persons in 2008 have received money from their children every month. Undeniable, the children have perceived as important for 
elderly as one of the financial sources in maintaining their life. However, there are no legal documents or policies stated that the children are obliged to give monthly allowance or money to their parent. It has been perceived as an individual practices or cultural tradition, no coercive power imposed. So, the increasing of retirement age to 60 years old especially in the public sector provides the chances for elderly to prepare themselves before they reach at the actual retirement age. This can be the sources of income to bear their own liabilities and can release the household burdens due to higher cost of living. Hence this new retirement age somehow is helping those aging workforce in maintaining their life.

\section{AGED IN THE GOVERNMENT SECTOR}

The issue of aging population also has spawned into the public sector. There has been a great deal of discussion and debate in recent years with regards to aging public sector workforces. Apparently, the public sector in Malaysian has been trapped by aged workforces [10] and currently, the number of public servant in Malaysia is about 1.4 million [11]. Due to that problem, Malaysian government has taken action by increasing the retirement age from 58 to 60 years old under Skim Saraan Malaysia (SSM). The extension of retirement age as announced by the government is an immediate solution but it might create a new problem in the future [12]. A deep thought and consideration must be forward-facing because the proficiency and performance of the public sector depend on the productivity of the workers. By increasing the age of retirement from 58 to 60 years it just provides short term solution whereby, those people might not be productive as before. This is because, the old aged might be affected by numerous health's related issues and can risk the organization's productivity [13]. It has been observed that, since Malaysian government has increased the retirement age, it causes the organizations reduce new entrances especially young workers and fresh graduate to be fill in into organization and this problem may lead to high graduate unemployment [14]. Conversely, Congress of Unions of Employees in the Public and Civil Services (CUEPACS) finds that, even though government increase the retirement age, there has been no evidence shows the deprivation of jobs towards younger workers [15]. The new entrance especially graduates need to move some miles ahead to be an innovative and critical thinking in creating employment or entrepreneurship opportunities for themselves and not become mentally-subsidized. As realizing this opportunities Malaysian government have launched many programs to encourage young generation to be involved in entrepreneurship activities. Ideally, entrepreneurship programs may help young generation to be more creative in providing job opportunities not only for them but for other people. It is a good touchstone for the country to produce a large pool of entrepreneurs within the country. Fluctuation of the world economy has led the country into the severe situation, less job supply. There has been for example, in year 1997 the economic crisis embedded, contraction of Malaysian economy inaugurated. Many of the workers especially in the private sectors have been retrenched due to crisis and worsening the country's condition. For the public sector, since the government restructured the executive level (considering the revenue and expenses) many of the positions have been merged in order to reduce operating expenditures, upsurge productivity instead.

\section{BRIDGING THE GAP}

An underlying of Malaysia situation, Malaysia now is heading towards knowledge based economy or known as KEconomy. The transformation from production based to knowledge based is a good indication for the country. In meeting national vision objective to be developed country by year 2020 (as mentioned in New Economic Model (NEM)) it is deemed important to produce more talent or human capitals that are capable to admin the country using our own mould. In fact, Malaysia is actually undergoing talent scarcity due to the increasing of inadequate standard of national education system as well as worsening brain drain problems that begin to take place (SEDAR Institute). Due to limited of time, lack of expertise and time constraint, the country has increased the retirement age and makes use of many senior workers (aged workers) by utilizing the available experience and knowledge. The costs are needed if the organization intents to train the new employees, until the high level and it is a waste if the organization just let them go early (CUEPACS). On the other hand, elderly is perceived as unproductive and might be affected by numerous health problems; therefore it would be difficult for them to find a new job after retirement age. Many employers refuse to hire elderly compare to young people since this cohort less effective in exerts their energy in performance. In fact, it would be financially hurt for the employers to pay the cost if the productivity is remaining low. The elderly also need to keep a pace with the current technology and a must for them to learn. The differences of generation $\mathrm{x}$ and $\mathrm{y}$ must be given ample time for further discussion.

\section{FINANCIAL SECURITY}

Financial security is really important for aged society. There is need for elderly to have proper financial planning as a fortress after getting retired. A proper financial planning is significant for elderly in sustaining their quality of live. Financial security refers to as having an appropriate financial strategy and adequate financial resources to satisfy needs or most wants of an individual or business. Undeniably, age above 58 years old is seems not vigorous and energetic in turning out their ability into certain expectation. Thus, by having financial security somehow can assist those elderly to keep secured after retired. In fact, they might not be able or not productive as before to work since their age exceeds the work's requirement. Besides the age, they were also facing difficulties in terms of health condition. Some organizations hesitate to endure ageing workers since their age can be affected by numerous health related issues and might jeopardize the productivity [13]. So, it relatively burden to organization especially in purchasing social insurance for ageing employees, while the 
productivity remains low. In addition, the implementation of privatization policy on healthcare lead to the social stratification class among the society [6]. It would be burden for elderly in getting those benefits and steering to another problem such as poverty.

There are several sources of income need to be considered by elderly after getting retired. According to research that had been done by [9], children are the major sources of income followed by pension, salary, business, agriculture activities and others. This has become the trend among old age whereby those people apparently depend on their children's support or allowances given such as per month. However, personal saving also has contributed towards financial security. Based on the research that had been done by [16], it indicates that only $19.0 \%$ of the pensioners actively intended for their savings. Research was conducted among 2055 public and private sectors in 2009 , showed that $73 \%$ of the respondents have savings for old age. Improper financial planning among elderly will lead to financial problems that will causes financial insecurity feeling. The financial problems have negative relationship with financial status [17], [18]. There are several financial problems basically faced by elderly without better financial planning after getting retired i.e. they will borrow money from .along., cheated from pyramid scheme, bad debt, asset repossesses, no emergency fund, borrowed money from others for living cost and cannot afford to pay bill punctually. It was found that, the most important financial problem among elderly were, they do not have emergency fund, borrow money from others and cannot afford to pay bill punctually [9].

\section{NATIONAL POLICY FOR The ELDERLy}

Many of Asian countries including Malaysia, co-residing with elderly or aged parents and providing aged care is a part and parcel of the cultural tradition. It has been practiced among those countries and children are the most responsible entity in providing aged care. However, with the modern life style, increasing number of elderly, the changing pattern of family from extended to nuclear types, these reasons have the deep impact on this cultural tradition. In response to this situation, Malaysian government has done several initiatives to protect ageing population or elderly such as by introducing National Policy for the Elderly. This policy is aimed $i{ }^{\circ}$ creating a society of elderly people who are contented and possess a high sense of self-worth and dignity, by optimizing their self-potential and ensuring that they enjoy every opportunity as well as care and protection as members of their family, society and nation , [19]. Even though this policy is a good initiative taken by the government as a preparation for ageing transition, but it must be addressed wisely by looking on the effects of elderly financial welfare. The elements of financial security and financing aspect - is absent from the Policy and only included as a sub-program [20]. The health care is received extensive attention but financing aspect is rare covered.

In contrast to Australia, ageing policy has been reflected by the different culture norms. It is focusing on consolidating and progressing reforms in order to make sure that elderly have the choice and access to quality aged care services while depend on the role of informal support [21]. Besides, in Australia, they give more attention on ageing'sdevelopment by placing them through community support and services. Therefore, it is well-timed for the country to review and analyse the current policy on elderly, be prepared to make a better changes and invest in quality aged care services.

\section{CONCLUSION}

Increased longevity is not a victory for the country but it might be a huge challenge for many aspects especially financial security, health care system and policy. Even though Malaysia is still considered as a country that relatively young population, but ageing population is progressively increasing. This situation has placed an amount of burden to the existing workforces, bear the current cost. Not only that, the cultural tradition in supporting the aged parents have changed, make aged become less secured. A comprehensive restructuring the policy for elderly is seems to be important, shows the government effort in dealing with this challenge. By considering and analysing other countries initiatives, Malaysian can reduce the existing gap, make the action become fruitful. This is because; aged society cannot be marginalized from country's development since they were contributed a lot towards the country achievements.

\section{REFERENCES}

[1] Banik and P. K. Bhaumik, "Ageing population, emigration and growth in Barbados," International Management Institute, New Delhi, India, 2006

[2] P. S. Hewitt, "The gray roots of Japan.s crisis," Asia program special report, pp. 4, 2003.

[3] M. Patrickson and R. Ranzijn, "Workforce ageing: the challenges for 21 st century management," International Journal of OrganisationalBehaviour, vol. 10, no. 4, pp. 729-739, 2003.

[4] R. Mat and H. Md. Taha, "Analysis of the 2000 round of censuses socio-economic characteristics of the elderly in Malaysia," Department of statistics Malaysia, 2003.

[5] Population of Asia. (2010). [Online]. Available: http://www.worldstat.info/Asia/Malaysia

[6] J. L. Powel and I. G. Cook, "Global ageing in comparative perspective: a critical discussion," International Journal of Sociology and Social Policy, vol. 29, pp. 388-400, 2009.

[7] C.Estes, S. Biggs, and C. Philipson, "Social theory, social policy and ageing," Open University press, Milton Keynes, 2003.

[8] J. Masud, S. A. Haron, and L. W. Gikonyo, "Gender differences in income sources of the elderly in Peninsular Malaysia,"Journal of Family Economic Issue, vol. 29, pp. 623-633, 2008

[9] T. A. Hamid and J. Masud, Financial well-being of older Malaysians, 2010.

[10] L. Boosman and D. Kristi, "Impacts of aging baby boomers on civil service workforce: A critical analysis of the literature," Walden University, 2008.

[11] B. Semasa. (3 October, 2012). [Online]. Available: http://beritasemasa.com/

[12] S. N. Yusoff and N. Kamarunzaman, "The extension of the retirement age: decent or deprived?" IEEE Symposium on Humanities, Science and Engineering, joint chapter, SHUSER 2012.

[13] D. A. Schwart and B. H. Kleiner, "The relationship between age and employment opportunities,"1999.

[14] SEDAR Institute, The Case for Malaysia to Raise the Retirement Age-SEDAR Institute: Awakens the Nation, 2010.

[15] Malaysiakini. CUEPACS mahu kerajaanwujudkangaji minimum. (2011). [Online]. Available: http://www.malaysiakini.com/newa/155445.

[16] K. G. Lim, “An empirical study of older workers. Attitude towards the retirement experience," Employee relation, vol. 25, no. 4, pp. 126 134,2002 
[17] S. A. De Vaney and R. T. Lytton, "Household insolvency: A review of household debt repayment, delinquency and bankruptcy," Financial Services Review, vol. 4, pp. 137, 156, 1995.

[18] E. T. Garman and R. E. Forgue, Personal finance, (7th ed.), Boston: Houghton Mifflin Co, 2006.

[19] Government of Malaysia, "National Senior Citizens Policy Action Plan 1999," Department of Social Welfare, Ministry of National Unity and Social Development, National Printing Department, Kuala Lumpur, 1999.

[20] O. F. Sim, "Ageing in Malaysia: national policy and future direction," University of Malaya, Kuala Lumpur, 2001.

[21] Australian Bureau of Statistics. Australian Demographic Statistics. [Online]. Available: http://www.abs.gov.au/.

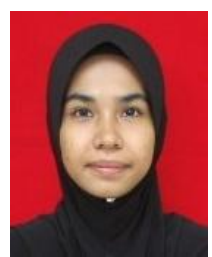

Siti Norfazlina Yusoff was born on January 2, 1986 in Kelantan, Malaysia. She graduated with master in Public Administration, (major in public administration) from UniversitiSains Malaysia (USM) in year 2010 and bachelor degree in Administrative Science and Policy Studies, from UniversitiTeknologi Mara (UiTM), 2006-2009.Currently, she is a lecturer at the Faculty of Administrative Science and Policy Studies, UniversitiTeknologi Mara (UiTM). She has written articles in the International Conference on Economics and Businesess Research (ICEBR) 2013, Symposium on Humanities, Science and Engineering Research (SHUSER 2012), and 3rd International Conference on Public Policy and
Social Sciences 2012 (ICoPS2012). With 3 years of working experience, she hopes to contribute her skills and knowledge to the development and welfare of the society at large.

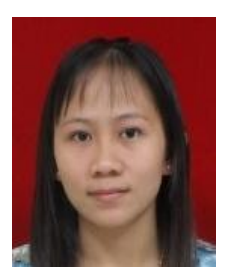

Geogiana Anak Buja was born in Sarawak, Malaysia on February 8, 1987. She obtained master degree from Universiti Teknologi Mara Shah Alam, Malaysia in year 2011, Master of Science in Computer Science (major Operating System, Information and Network Security and Networking). She obtained bachelor degree from Universiti Teknologi Mara Shah Alam Malaysia in year 2009. bachelor of Science in Netcentric Computing (major Operating System, Information and Network Security and Networking).She has experiences in supervising the bachelor degree students' final year project focusing on networking and information security. She has presented her department in delivering the contents of Netcentric Computing Programme. Have two years experiences taught Human Computer Interaction and Information Retrieval in Universiti Tun Abdul Razak, Malaysia (2009-2011). She has written an article in the Proceedings of Technology, Science, Social Sciences, Humanities International Conference (TeSSHI) 2012. Currently, she actively involved in three researches of mobile computing. Ms. Buja is actively involved in Cisco. She is an instructor of Cisco in Universiti Teknologi Mara Kedah, Malaysia. Besides, Ms. Buja also involved in with Infosys Limited. 